\title{
OPEN Effect of extracorporeal shock wave therapy on keratinocytes derived from human hypertrophic scars
}

\author{
Hui Song Cui ${ }^{1,4}$, So Young $\mathrm{Joo}^{2,4}$, Yoon Soo Cho ${ }^{2}$, Ji Heon Park' ${ }^{1}$, Yu Mi Ro ${ }^{1}$, June-Bum Kim ${ }^{3 凶}$ \& \\ Cheong Hoon $\mathrm{Seo}^{2 \bowtie}$
}

Hypertrophic scars represent a common complication in burn patients. In addition to cosmetic defects, they may cause serious sensory abnormalities such as pain and itching, severe dysfunction depending on the site, and emotional disorders such as anxiety and depression. The present study aimed to identify the molecular mechanisms underlying the use of extracorporeal shock wave therapy in keratinocytes. Keratinocytes derived from hypertrophic scar tissue were cultured and expression of proliferation markers (keratin 5 and 14), activation markers (keratin 6 and 17), differentiation markers (keratin 1, 10, and involucrin), apoptosis factors (Bax, Bcl2, and Caspase 14), and proliferation/differentiation regulators (p21 and p27) was investigated to compared with that of those in keratinocytes derived from normal skin tissue. Scar-derived keratinocytes were treated with extracorporeal shock waves under 1000 impulses at $0.1,0.2$, and $0.3 \mathrm{~mJ} / \mathrm{mm}^{2}$. Shock waves altered the molecular pattern of proliferation, activation, differentiation, and apoptosis, as well as proliferation/ differentiation regulators, including Bax, Bcl2, ASK1, p21, p27, and Notch1. In summary, we show that extracorporeal shock wave therapy regulates the proliferation and differentiation of keratinocytes derived from hypertrophic scar to maintain normal epidermal integrity.

Hypertrophic scar hyperplasia is one of the most common complications after burn injury. Whereas the exact mechanism remains unknown, the phenomenon is characterized by the pathological proliferation of scar tissue caused by abnormal wound healing and scar maturation processes ${ }^{1}$. It is accompanied by excessive deposition of extracellular matrix, which not only increases scar thickness and decreases elasticity of the scar skin, but also causes continuous scar pain and itching in burn patients ${ }^{1,2}$. In addition, thicker scars in the joint area decrease the range of motion of the joint and become an important impediment to daily life movements and walking during the rehabilitation process ${ }^{1}$.

Various treatments, such as compression clothing, silicone gel, scar massage, laser treatment, intralesional injection, and surgical removal, are combined in clinical practice to treat hypertrophic scars in burn patients ${ }^{3}$. Triamcinolone is used for intralesional injection treatment, effectively reducing scar thickness and inhibiting proliferation ${ }^{3}$. However, as it affects also continuous progression of scar growth ${ }^{3}$, it is used only for localized scars. Therefore, a new, non-invasive, and effective treatment that can be applied continuously on a wide scar area is required.

Extracorporeal shock wave therapy (ESWT) is used to reduce inflammation, diminish pain, and regenerate soft tissues in musculoskeletal diseases ${ }^{4}$. A single treatment of ESWT upregulated with prolonged period time, 25-30 key pro-angiogenic gene expression that are decreased in both diabetic and wound healing models. ESWT inducing pro-angiogenic factors included for platelet-cell adhesion molecule-1 (PECAM-1), vascular endothelial growth factor (VEGF) and its receptor (VEGFR), endothelial nitric-oxide synthase (eNOS), and hypoxia-inducible factor $1 \alpha(\mathrm{HIF}-1 \alpha)^{5}$. ESWT not only induced endothelial cell proliferation, but also enhanced proliferation of other cell types $^{6-8}$. Several previous studies both in vitro and vivo have shown an anti-inflammatory mechanism of ESWT, which treatment inhibited NF- $\kappa \mathrm{B}$ activation and decreased oxygen radical production, leukocyte

${ }^{1}$ Department of Rehabilitation Medicine, Burn Institute, Hangang Sacred Heart Hospital, College of Medicine, Hallym University, Seoul 07247, Korea. 'Department of Rehabilitation Medicine, Hangang Sacred Heart Hospital, College of Medicine, Hallym University, Seoul 07247, Korea. ${ }^{3}$ Department of Pediatrics, Hangang Sacred Heart Hospital, College of Medicine, Hallym University, Seoul 07247, Korea. ${ }^{4}$ These authors contributed equally: Hui Song Cui and So Young Joo. ${ }^{\varpi}$ email: hoppdoctor@hanmail.net; chseomd@gmail.com 
infiltration, chemokine expression, and pro-inflammatory cytokine expression ${ }^{9-11}$. In recent our study, shown ESWT down-regulated transforming growth factor beta 1 (TGF- $\beta 1$ ) expression and reversed epithelial mesenchymal transition (EMT) in fibroblast derived from $\mathrm{HTS}^{12}$. The signal transduction associated with above events by ESWT is not clear. However, the activation of ERK1/2 or p38 MAPK may be responsible for the biological effects of ESWT ${ }^{8,13,14}$. Moreover, it has been reported to improve perfusion, ameliorate lymph circulation in patients with lymphedema, stimulate osteoblasts and union in fractures showing nonunion for more than 6 months, and promote regeneration of damaged peripheral nerves ${ }^{15}$. However, so far, the application of extracorporeal shock waves to treat hypertrophic scars resulting from burns has been limited to animal models ${ }^{16}$.

Although normal epithelial cells actively interact with interstitial fibroblasts, they come from most studies on the etiology of hypertrophic scars have revealed pathological proliferation of the dermis ${ }^{1}$. Although the normal epidermal keratinocytes actively interact with dermal fibroblasts ${ }^{17}$, little is known about whether keratinocytes seen in hypertrophic scars play a particular role in scar proliferation. A study using a tissue-engineered human skin model showed that pathological keratinocytes in the epidermis induced fibrotic endothelial matrix formation and inhibited extracellular matrix degrading factors, resulting in hypertrophic scar formation ${ }^{18}$. Therefore, examining the characteristics of epidermal tissue-derived keratinocytes, which many studies have focused on, will provide basic data for developing new treatments against thickening burn scars.

Previously, we reported the therapeutic effects of ESWT on scar pain and pruritus in burn patients with hypertrophic scar ${ }^{19,20}$, and showed that treatment changed the levels of hypertrophic scar-related molecules in fibroblasts derived from hypertrophic scars ${ }^{12}$. Examining the effect of extracorporeal shock waves on keratinocytes derived from hypertrophic scar tissue at the molecular level will provide important evidence about the effectiveness of this therapy for hypertrophic scar treatment.

\section{Methods}

Primary epidermal keratinocyte culture. All experimental protocols of this study were approved by Institutional Review Board of Hallym University Hangang Sacred Heart Hospital, and were carried out in compliance with the guidelines (Hallym University Hangang Sacred Heart Hospital Institutional Review Board 2014-062). Written informed consent was obtained from all subjects. After that, the procedure of primary cell culture was as published previously ${ }^{21}$. The hypertrophic scar tissue and normal skin tissue are paired from four patients that were obtained during surgical procedure, washed with $70 \%$ ethanol and cold phosphate-buffered saline containing antibiotics and antimycotics (Gibco, Life Technologies, Carlsbad, CA, USA). The tissue was cut into 2-4-mm-wide pieces, which were placed in $50-\mathrm{mL}$ conical tubes containing $30 \mathrm{~mL}$ dispase II $(0.5 \mathrm{mg} / \mathrm{mL}$; Gibco) solution and agitated for $16 \mathrm{~h}$ at $4^{\circ} \mathrm{C}$. After digestion, the epidermis was obtained from the sample tissues by sterile forceps, and then digested with TrypLE ${ }^{m}$ Express Enzyme (Gibco) at $37^{\circ} \mathrm{C}$ for $45 \mathrm{~min}$. The solutions were added with KGM-Gold ${ }^{\mathrm{m}}$ keratinocyte growth medium containing supplements (Lonza Bioscience, Basel, Switzerland) to the enzyme, and then filtered and centrifuged at $1500 \mathrm{rpm}$ for $5 \mathrm{~min}$. The pellet was suspended in the medium and cultivated at $37^{\circ} \mathrm{C}$ in a $5 \% \mathrm{CO}_{2}$ atmosphere. Human normal keratinocytes (HNKs) and human hypertrophic scar keratinocytes (HTSKs) were used for future experiments at passage 1 or 2 .

ESWT device and cell treatment. Keratinocytes were collected from cell culture dish by dissociated with Accutase cell detachment solution (Thermo Fisher Scientific, Waltham, MA, USA) and suspended in complete medium in a $4.5-\mathrm{cm}$-long conical tubes at $2.0 \times 10^{5} / \mathrm{mL}$. The cells treated a focused shock wave generated from an electromagnetic cylindrical coil source using Duolith SD-1 ${ }^{\circ}$ device (StorzMedical, Tägerwilen, Switzerland). Cells were exposure to 1000 impulses $/ \mathrm{cm}^{2}$ under an energy flux density $\left(0.1,0.2\right.$, and $\left.0.3 \mathrm{~mJ} / \mathrm{mm}^{2}\right)$ and a frequency $(4 \mathrm{~Hz})$. After ESWT, that cells collected, centrifuged and further cultivated in complete medium in T75 culture plates. Cultivation for $24 \mathrm{~h}$ or $72 \mathrm{~h}$, the cells collected, and used to analysis of mRNA and protein expression.

Quantitative real-time PCR. Total RNA was extracted using a ReliaPrepTM RNA Miniprep system (Promega, Madison, WI, USA) according to the manufacturer's instructions. RNA concentration was measured, cDNA was synthesized, and quantitative real-time PCR were performed as previously described ${ }^{12,21}$. The primer sequences are listed in Table 1 . Target gene mRNA was normalized using the $2^{-\Delta \Delta \mathrm{Ct}}$ method.

Western blotting analysis. HNKs or HTSKs were harvested and lysed in ice-cold RIPA buffer (Cell Signaling Technology, Danvers, MA, USA) pre-added a complete phosphatase inhibitor cocktail (Roche, Basel, Switzerland) and protease inhibitor cocktail (Sigma, St. Louis, MO, USA), and maintained for $1 \mathrm{~h}$ at $4{ }^{\circ} \mathrm{C}$ with constant agitation. The cell lysates were centrifuged for $15 \mathrm{~min}$ at $13,000 \times g$ and $4{ }^{\circ} \mathrm{C}$, and the protein concentration was measured with a BCA kit (Thermo Fisher Scientific). Electrophoresis, primary and secondary antibody attachment, development (protein detection), and quantification were performed as previously described ${ }^{12,21}$. The primary antibodies are listed in Table 2. Target protein expression was normalized with $\beta$-actin, and expressed as ratio of HNK or un-treated controls (in ESWT treatment experiment).

Statistical analysis. All experimental results are presented with the mean \pm standard deviation (SD). Comparisons between two groups were performed using the Mann-Whitney U test. Statistical analyses were performed using PASW statistics 24 (SPSS Inc., Chicago, IL, USA), and $P<0.05$ was considered statistically significant. 


\begin{tabular}{|l|l|l|}
\hline Gene & Forward $\left(\mathbf{5}^{\prime} \rightarrow \mathbf{3}^{\prime}\right)$ & Reverse $\left(\mathbf{5}^{\prime} \rightarrow \mathbf{3}^{\prime}\right)$ \\
\hline KRT1 & TGGATGGTGCTTATATGAC & GACAACTCTGCTTGGTAG \\
\hline KRT5 & GTGGAAGACTTCAAGAACAA & TAGGCAGCATCTACATCC \\
\hline KRT6A & TGAAGAAGGATGTGGATG & ATCATACAAGGCTCTCAG \\
\hline KRT10 & GATTCTCAACCTAACAACTG & GCTACCTCATTCTCATACT \\
\hline KRT14 & GCTGAGATCAAAGACTACA & AGAAGGACATTGGCATTG \\
\hline KRT17 & ATCCTGCTGGATGTGAAGACGC & TCCACAATGGTACGCACCTGAC \\
\hline$I V L$ & GGACTGCCTGAGCAAGAATGTG & TAA GCT GCT GCT CTG GGT TT \\
\hline NOTCH1 & AGCCTCAACGGGTACAAG & TTGACACAAGGGTTGGATTC \\
\hline CASP 14 & CCTGTTGTCACCTTGCTAT & GTCCTTGCCTCTGTCTTAC \\
\hline$B A X$ & CCTTTTGCTTCAGGGTTTCA & CCATGTTACTGTCCAGTTCG \\
\hline$B C L 2$ & TGCGGCCTCTGTTTGATTT & AGGCATGTTGACTTCACTTGT \\
\hline ACTB & AGAGCTACGAGCTGCCTGAC & AGCACTGTGTTGGCGTACAG \\
\hline
\end{tabular}

Table 1. Real-time PCR primer sequences.

\begin{tabular}{|l|l|l|l|}
\hline Target & Host & Dilution & Company (Cat. No.) \\
\hline Keratin 1 & Rabbit & $1: 1000$ & Abcam (ab93652) \\
\hline Keratin 5 & Rabbit & $1: 2000$ & Abcam (ab52635) \\
\hline Keratin 6 & Mouse & $1: 2000$ & Abcam (ab18586) \\
\hline Keratin 14 & Rabbit & $1: 2000$ & Abcam (ab181595) \\
\hline Keratin 17 & Rabbit & $1: 2000$ & Abcam (ab10975) \\
\hline Involucrin & Mouse & $1: 500$ & Thermo Fisher Scientific (MA5-11803) \\
\hline ASK 1 & Rabbit & $1: 1000$ & Abcam (ab45178) \\
\hline Notch 1 & Rabbit & $1: 1000$ & Abcam (ab52627) \\
\hline Caspase 14 & Rabbit & $1: 1000$ & Abcam (ab174847) \\
\hline Bax & Rabbit & $1: 1000$ & Abcam (ab199677) \\
\hline Bcl2 & Rabbit & $1: 1000$ & Abcam (ab196495) \\
\hline P21 & Rabbit & $1: 1000$ & Abcam (ab109199) \\
\hline P27 & Rabbit & $1: 1000$ & Abcam (ab32034) \\
\hline$\beta$-actin & Rabbit & $1: 2000$ & Cell Signaling Technology (4967S) \\
\hline$\beta$-actin & Mouse & $1: 1000$ & Santa Cruz Technology (sc-47778) \\
\hline
\end{tabular}

Table 2. Western blot primary antibodies.

\section{Results}

Characterization of HTSKs. A series of clear markers are expressed in the process of keratinocyte proliferation to differentiation. For example, classically considered that keratin 5 and 14 are proliferation marker, keratin 1,10 , and involucrin are differentiation marker, and keratin 6 and 16/17 are activation marker ${ }^{22}$. The expression of keratin 5 and 14 at mRNA and protein levels was no significant difference between HTSKs and HNKs (keratin 5-mRNA: $1.26 \pm 0.37$, protein: $1.206 \pm 0.26$-fold; keratin $14-$ mRNA: $1.16 \pm 0.39$, protein: $1.09 \pm 0.38$-fold, respectively; $P>0.05$ ) (Figure S1A-D). The expression of keratin 6 and 17 at mRNA and protein was markedly higher in HTSKs than that of those in HNKs (keratin 6-mRNA: 2.16 \pm 0.48 , protein: $1.92 \pm 0.46$-fold increase; keratin $17-$ mRNA: $1.94 \pm 0.38$, protein: $1.83 \pm 0.26$-fold increase, respectively; $P<0.05$ ) (Fig. 1 ).

The mRNA and protein expression of keratin 1 was significantly higher in HTSKs than that of those in HNKs (mRNA: $2.33 \pm 0.32$, protein: $1.63 \pm 0.26$-fold increase, respectively; $P<0.05$ ) (Fig. $2 \mathrm{~A}, \mathrm{~B}$ ). In contrast, the mRNA and protein expression of keratin 10 was significantly lower in HTSK than that of those in HNK (mRNA: $0.19 \pm 0.19$, protein: $0.50 \pm 0.26$-fold decrease, respectively; $P<0.05$ ) (Fig. 2 C,D). Moreover, involucrin expression at mRNA and protein levels was significantly higher in HTSKs than that of those in HNKs (mRNA: $3.03 \pm 0.30$, protein: $2.28 \pm 0.31$ - fold increase, respectively; $P<0.05$ ) (Fig. $2 \mathrm{E}, \mathrm{F}$ ).

The pro-apoptotic factor, Bax expression at mRNA and protein levels was slightly increased in HTSKs, but there is no significant difference between HTSKs and HNKs (mRNA: $1.23 \pm 0.21$, protein: $1.11 \pm 0.14-$ fold increase, respectively; $P>0.05$ ) (Figure $\mathrm{S} 1 \mathrm{E}, \mathrm{F}$ ). In contrast, the anti-apoptotic factor, Bcl2 expression at mRNA and protein levels was significantly higher in HTSK than that of those in HNKs (mRNA: $3.65 \pm 0.81$, protein: $2.0 \pm 0.36$ - fold increase, respectively; $P<0.05$ ) (Fig. 3A,B). The mRNA and protein levels of caspase 14 , which is a keratinocyte specific caspase was significantly lower in HTSKs than that of those in HNKs (mRNA: 0.355 \pm 0.16 , protein: $0.43 \pm 0.22$-fold decrease, respectively; $P<0.05$ ) (Fig. 3C,D).

The p 21 and p27 are cell cycle regulator, to control proliferation to differentiation in keratinocyte, both were significantly higher at both mRNA and protein levels in HTSKs than that of those in HNKs (p21-mRNA: 
A

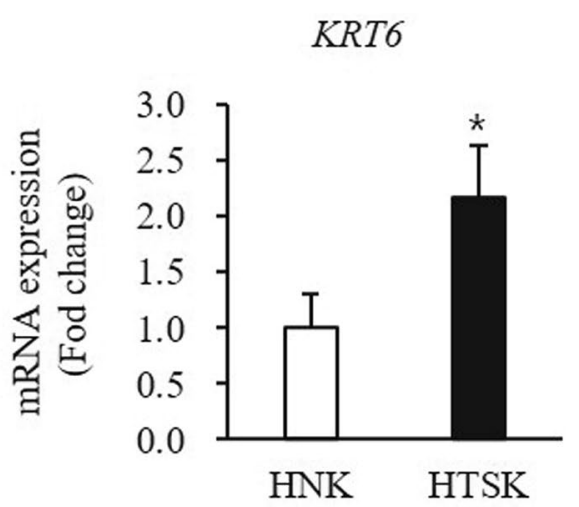

$\mathrm{C}$

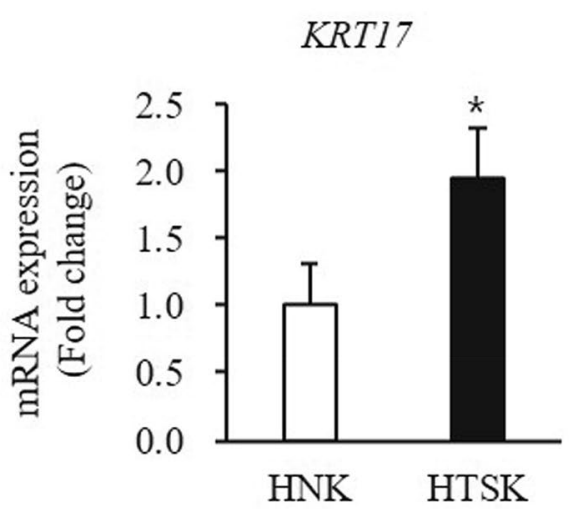

B

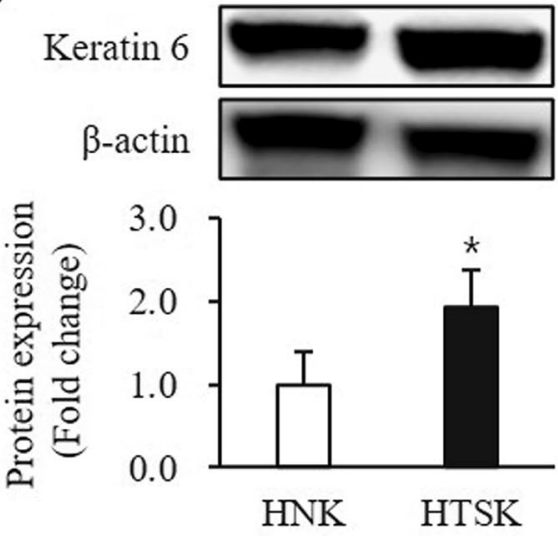

$\mathrm{D}$

\section{Keratin 17}
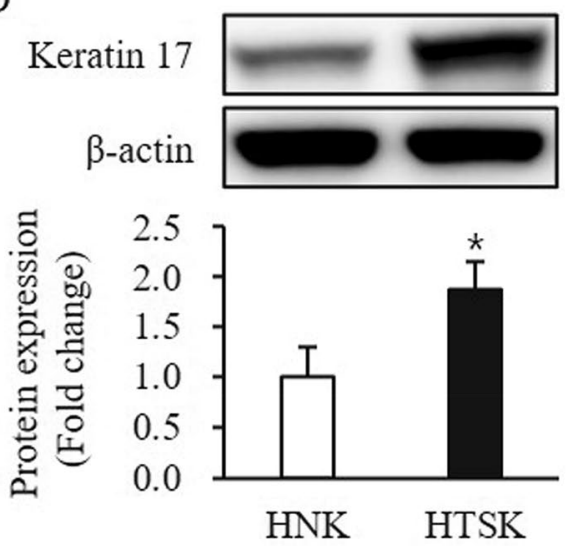

Figure 1. Expression of activation markers in HTSKs. Significantly increased mRNA levels of genes encoding keratin 6 (KRT6) (A) and keratin 17 (KRT17) (C) in HTSKs compared with those in HNKs. Significantly increased protein levels of keratin 6 (B) and keratin 16 (D) in HTSKs compared with those in HNKs. NHKs and HTSKs were primary cultured from normal skin tissues and HTS tissues, respectively. In the fold change, HNKs marked as value 1; HNK, human normal keratinocyte; HTSK, hypertrophic scar keratinocyte; ${ }^{\star} P<0.05$ for HTSK vs. the corresponding matched HNK. Data represent means \pm SD; $n=4(\mathrm{HNK})$ and $\mathrm{n}=4$ (HTSK).

$6.32 \pm 1.05$, protein: $2.23 \pm 0.49$-fold increase; p27-mRNA: $5.55 \pm 1.23$, protein: $1.73 \pm 0.30$-fold increase, respectively; $P<0.05$ ) (Fig. 4).

These results indicate that HTSKs are exhibiting an activated, over-differentiated, and augmented anti-apoptosis phenotype.

Effect of ESWT on expression of proliferation and activation marker in HTSKs. ESWT had no effect on the expression of proliferation marker keratin 5 at mRNA and protein levels in HTSKs $24 \mathrm{~h}$ and $72 \mathrm{~h}$ after ESWT, compared to untreated control (mRNA: $0.1-0.97 \pm 0.11,0.2-0.95 \pm 0.10$, and $0.3-0.97 \pm 0.10$ fold at $24 \mathrm{~h}, 0.1-1.13 \pm 0.09,0.2-1.05 \pm 0.12$, and $0.3-1.17 \pm 0.13$-fold at $72 \mathrm{~h}$, protein: $0.1-0.93 \pm 0.09$, $0.2-0.95 \pm 0.10$, and $0.3-0.99 \pm 0.12$-fold at $24 \mathrm{~h}, 0.1-0.99 \pm 0.09,0.2-1.01 \pm 0.10$, and $0.3-1.03 \pm 0.11$-fold at $72 \mathrm{~h}$, respectively; $P>0.05$ ) [Figure S2]. Another proliferation marker keratin 14 at $\mathrm{mRNA}$ and protein levels no difference between ESWT treatment and untreated control at $24 \mathrm{~h}$ after ESWT with $0.1 \mathrm{~mJ} / \mathrm{mm}^{2}$ (mRNA: $0.1-0.96 \pm 0.11$, protein: $1.05 \pm 0.12$-fold at $24 \mathrm{~h}, P>0.05$ ) (Fig. $5 \mathrm{~A}, \mathrm{~B})$. However, keratin 14 at mRNA and protein levels in HTSKs $24 \mathrm{~h}$ and $72 \mathrm{~h}$ after ESWT with 0.2 and $0.3 \mathrm{~mJ} / \mathrm{mm}^{2}$ significantly lower and higher than that of those in untreated control cells (mRNA: $0.2-0.65 \pm 0.07$ and $0.3-0.42 \pm 0.10$, protein: $0.2-0.80 \pm 0.10$ and $0.3-0.61 \pm 0.08$-fold decrease at $24 \mathrm{~h}$, mRNA: $0.1-1.86 \pm 0.19,0.2-2.33 \pm 0.29$, and $0.3-2.64 \pm 0.33$, protein: $0.1-1.29 \pm 0.10,0.2-1.40 \pm 0.11$, and $0.3-1.53 \pm 0.12$-fold increase at $72 \mathrm{~h}$, respectively; $P<0.05$ ) (Fig. 5A,B). The activation marker keratin 6 at mRNA and protein levels in HTSKs $24 \mathrm{~h}$ and $72 \mathrm{~h}$ significantly higher and lower than that of those in untreated control cells (mRNA: $0.1-1.97 \pm 0.18,0.2-2.35 \pm 0.22$, and $0.3-1.62 \pm 0.29$-fold increase at $24 \mathrm{~h}, 0.1-0.66 \pm 0.07,0.2-0.63 \pm 0.09$, and $0.3-0.43 \pm 0.05$-fold decrease at $72 \mathrm{~h}$, protein: $0.1-1.36 \pm 0.10,0.2-1.49 \pm 0.11$, and $0.3-1.69 \pm 0.19$-fold increase at $24 \mathrm{~h}, 0.1-0.80 \pm 0.09,0.2-$ $0.78 \pm 0.08$, and $0.3-0.60 \pm 0.08$-fold decrease at $72 \mathrm{~h}$, respectively; $P<0.05)$ (Fig. 5C,D). 
A

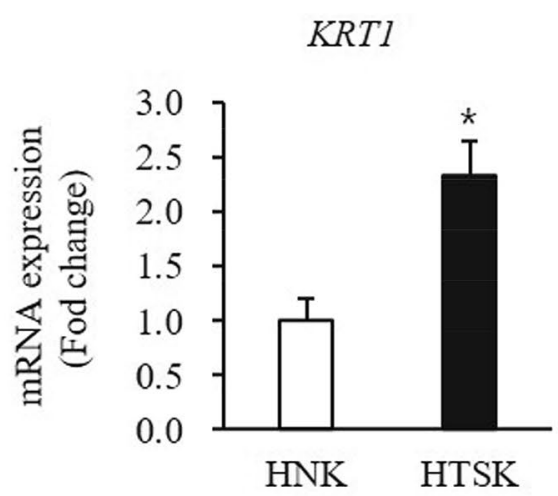

C

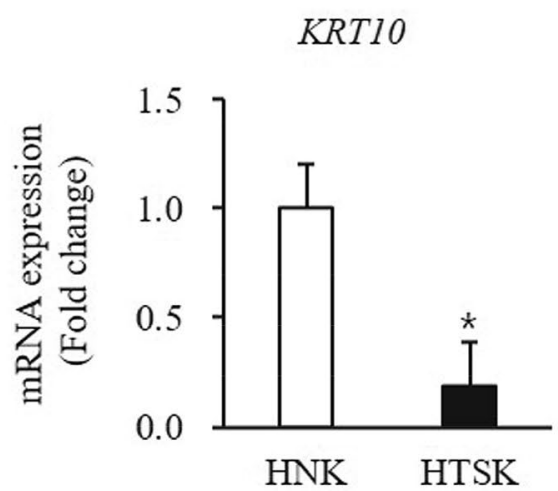

E

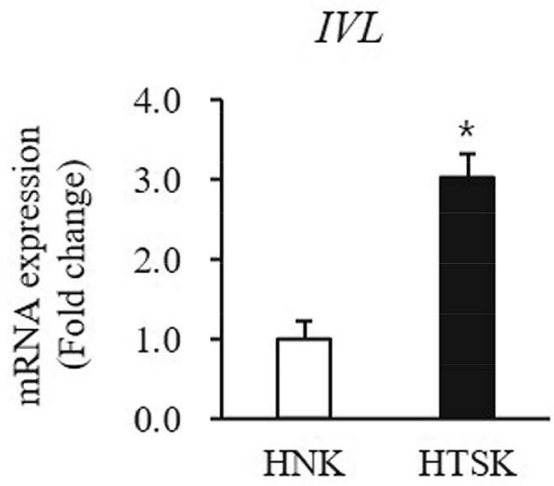

B

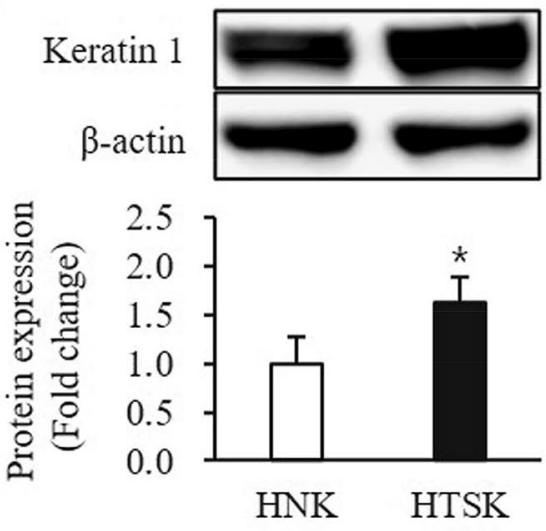

D

Keratin 10

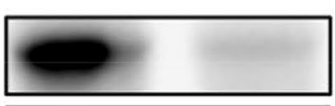

$\beta$-actin

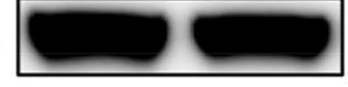

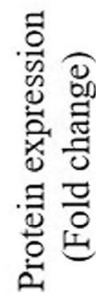

1.5
1.0
0.5
0.0

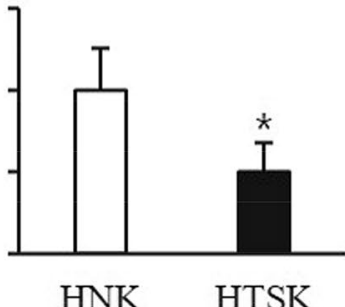

F

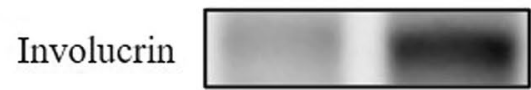

$\beta$-actin

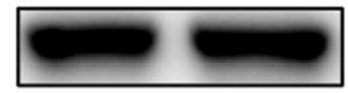

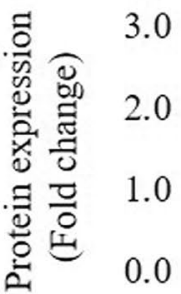

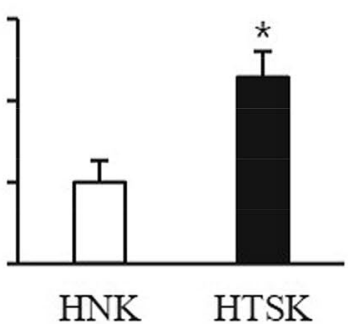

Figure 2. Expression of differentiation markers in HTSKs. Significantly increased mRNA levels of genes encoding keratin 1 (KRT1) (A), decreased mRNA levels of genes encoding keratin 10 (KRT10) (C), and increased mRNA levels genes encoding involucrin $(I V L)(\mathbf{E})$ in HTSKs compared with those in HNKs. Significantly increased protein levels of keratin 1 (B) and decreased protein levels of keratin 10 (D) and increased protein levels of involucrin (F) in HTSKs compared with those in HNKs. NHKs and HTSKs were primary cultured from normal skin tissues and HTS tissues, respectively. In the fold change, HNKs marked as value 1; HNK, human normal keratinocyte; HTSK, hypertrophic scar keratinocyte; ${ }^{\star} P<0.05$ for HTSK vs. the corresponding matched HNK. Data represent means $\pm S D ; n=4(\mathrm{HNK})$ and $n=4$ (HTSK).

Keratin 17 at mRNA and protein levels in HTSKs $24 \mathrm{~h}$ after all ESWT regimens significantly higher than that of those in untreated control cells (mRNA: $0.1-2.04 \pm 0.15,0.2-2.05 \pm 0.21$, and $0.3-2.12 \pm 0.22$-fold increase, protein: $0.1-1.51 \pm 0.09,0.2-1.53 \pm 0.10$, and $0.3-1.56 \pm 0.10$-fold increase at $24 \mathrm{~h}$, respectively, $P<0.05)$ (Fig. 5E,F). However, they are no difference at $72 \mathrm{~h}$ after ESWT (mRNA: $0.1-0.96 \pm 0.09,0.2-0.93 \pm 0.10$, 
A

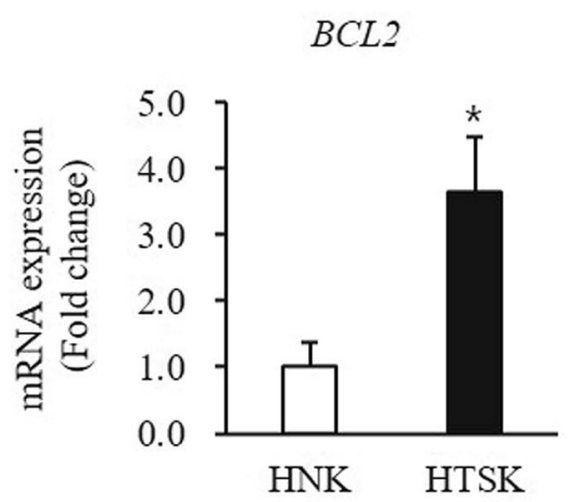

$\mathrm{C}$

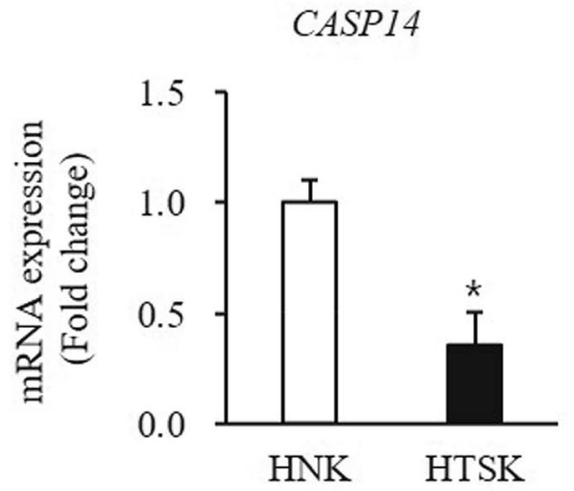

B

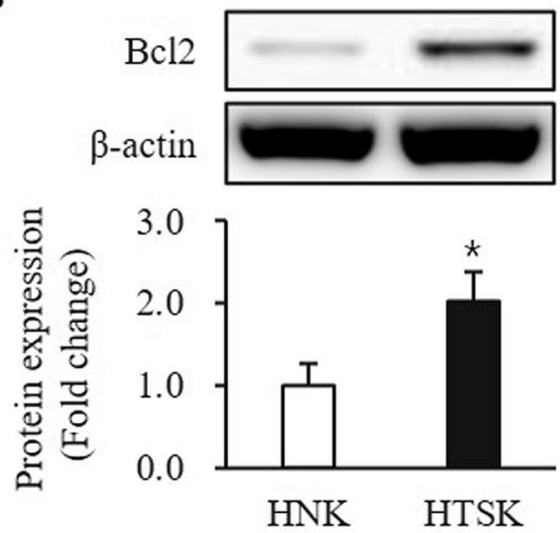

$\mathrm{D}$

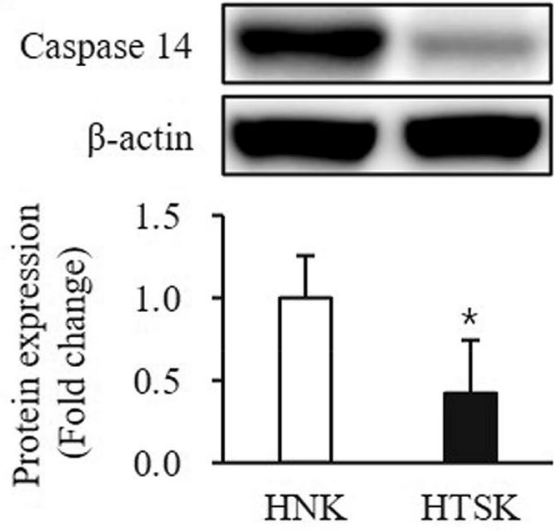

Figure 3. Expression of apoptosis-related factors in HTSKs. Significantly increased mRNA levels of genes encoding bcl2 (BCL2) (A) and decreased mRNA levels of genes encoding caspase 14 (CASP14) (C) in HTSKs compared with those in HNKs. Significantly increased protein levels of bcl2 (B) and decreased protein levels of caspase 14 (D) in HTSKs compared with those in HNKs. NHKs and HTSKs were primary cultured from normal skin tissues and HTS tissues, respectively. In the fold change, HNKs marked as value 1; HNK, human normal keratinocyte; HTSK, hypertrophic scar keratinocyte; ${ }^{\star} P<0.05$ for HTSK vs. the corresponding matched HNK. Data represent means $\pm S D ; n=4(H N K)$ and $n=4$ (HTSK).

and $0.3-0.94 \pm 0.09$-fold, protein: $0.1-0.95 \pm 0.11,0.2-0.94 \pm 0.12$, and $0.3-0.88 \pm 0.10$-fold increase at $24 \mathrm{~h}$, respectively, $P>0.05$ ) (Fig. 5E,F). In addition, the protein expression of keratin 6, 14, and 17 in HNKs after ESWT was measured by western blotting. The proliferation marker keratin 14 expression was unaffected after all ESWT regimens $(0.1-1.05 \pm 0.08,0.2-1.0 \pm 0.09$, and $0.3-1.02 \pm 0.09$-fold at $24 \mathrm{~h}, 0.1-0.99 \pm 0.10,0.2-1.02 \pm 0.10$, and $0.3-1.03 \pm 0.10$-fold at $72 \mathrm{~h}$, respectively; $P>0.05$ ) (Figure S3A). However, activation marker keratin 6 expression at protein levels in HNKs $24 \mathrm{~h}$ and $72 \mathrm{~h}$ after ESWT with $1000 \mathrm{impulses} / \mathrm{cm}^{2}$ at $0.1,0.2$. and $0.3 \mathrm{~mJ} /$ $\mathrm{mm}^{2}$ significantly higher and lower than that of those in untreated cells $(0.1-1.33 \pm 0.11,0.2-1.54 \pm 0.13$, and $0.3-1.85 \pm 0.19$-fold increase at $24 \mathrm{~h}, 0.1-0.34 \pm 0.04,0.2-0.28 \pm 0.03$, and $0.3-0.27 \pm 0.04$-fold decrease at $72 \mathrm{~h}$, respectively; $P<0.05$ ) (Figure S3B). The keratin 17 is also an activation marker, which protein expression was unchanged after all ESWT regimens, compared to untreated control cells $(0.1-1.04 \pm 0.09,0.2-1.05 \pm 0.10$, and $0.3-1.08 \pm 0.10$-fold at $24 \mathrm{~h}, 0.1-0.95 \pm 0.10,0.2-0.96 \pm 0.09$, and $0.3-0.94 \pm 0.09$-fold at $72 \mathrm{~h}$, respectively; $P>0.05$ ) (Figure S3C). These results suggest ESWT may regulate that HTSKs proliferation.

Effect of ESWT on expression of differentiation marker in HTSKs. The early differentiation marker keratin 1 expression at mRNA and protein levels in HTSKs $24 \mathrm{~h}$ and $72 \mathrm{~h}$ after ESWT significantly lower and higher than that of those in untreated control cells (mRNA: $0.1-0.67 \pm 0.12,0.2-0.55 \pm 0.10$, and $0.3-0.44 \pm$ 0.12 -fold decrease at $24 \mathrm{~h}, 0.1-1.76 \pm 0.09,0.2-2.05 \pm 0.12$, and $0.3-2.27 \pm 0.13$-fold increase at $72 \mathrm{~h}$, protein: $0.1-0.78 \pm 0.08,0.2-1.61 \pm 0.06$, and $0.3-0.58 \pm 0.07$-fold decrease at $24 \mathrm{~h}, 0.1-1.32 \pm 0.10,0.2-1.41 \pm 0.11$, and $0.3-1.46 \pm 0.12$-fold increase at $72 \mathrm{~h}$, respectively; $P<0.05$ ) (Fig. 6A,B). The late differentiation marker involucrin expression at mRNA and protein levels in HTSKs $24 \mathrm{~h}$ after ESWT under $0.1 \mathrm{~mJ} / \mathrm{mm}^{2}$ not significantly changed, when compared to that of those in untreated control cells (mRNA: $1.07 \pm 0.12$, protein: $1.09 \pm$ 0.12, respectively; $\mathrm{P}>0.05$ ) (Fig. 6C,D). However, they at mRNA and protein levels in HTSKs $24 \mathrm{~h}$ after ESWT under 0.2 and $0.3 \mathrm{~mJ} / \mathrm{mm}^{2}$ were significantly higher than that of those in untreated cells (mRNA: $0.2-3.77 \pm$ 
A

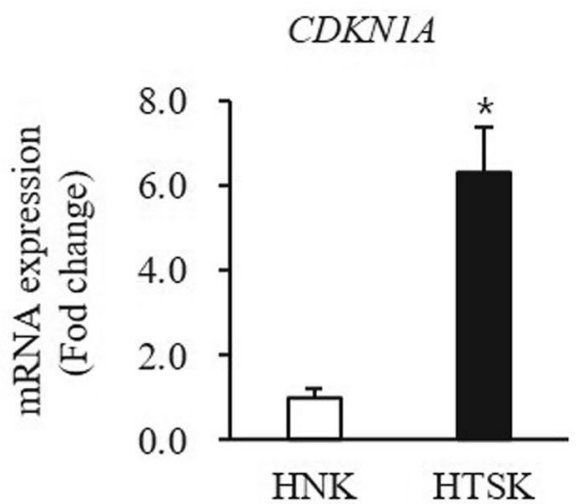

$\mathrm{C}$

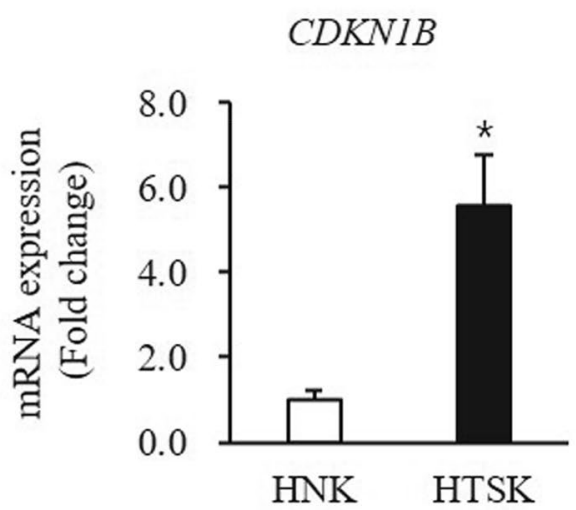

B

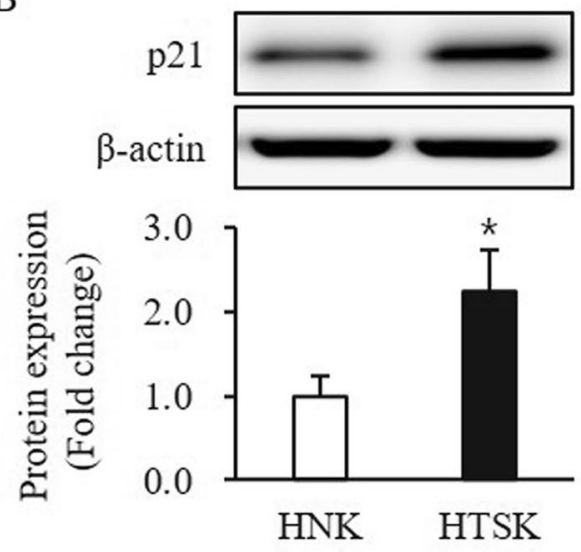

$\mathrm{D}$

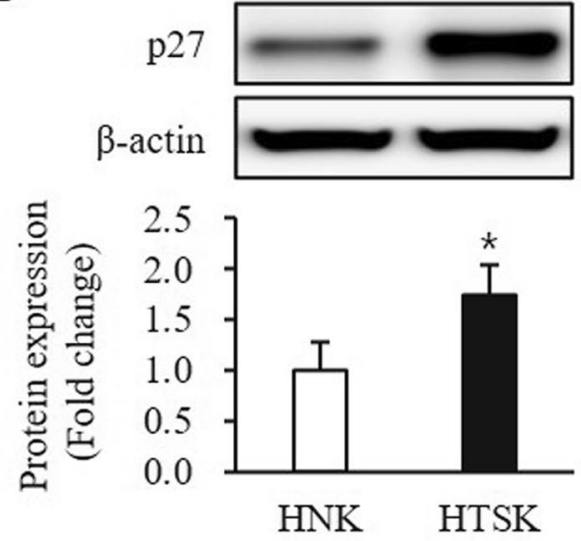

Figure 4. Expression of proliferation/differentiation regulators in HTSKs. Significantly decreased mRNA levels of genes encoding p21 (CDKN1A) (A) and p27 (CDKN1B) (C) in HTSKs compared with those in HNKs. Significantly decreased protein levels of p21 (B) and p27 (D) in HTSKs compared with those in HNKs. NHKs and HTSKs were primary cultured from normal skin tissues and HTS tissues, respectively. In the fold change, HNKs marked as value 1 ; HNK, human normal keratinocyte; HTSK, hypertrophic scar keratinocyte; ${ }^{\star} P<0.05$ for HTSK vs. the corresponding matched HNK. Data represent means \pm SD; $n=4(\mathrm{HNK})$ and $n=4(\mathrm{HTSK})$.

$0.46,0.3-4.15 \pm 0.39$, protein: $0.2-2.69 \pm 0.30,0.3-3.13 \pm 0.28$, respectively; $P<0.05$ ) (Fig. $6 \mathrm{C}, \mathrm{D}$ ). Moreover, they at mRNA and protein levels $72 \mathrm{~h}$ after ESWT under all regimens were significantly lower than that of those in untreated control cells (mRNA: $0.1-0.59 \pm 0.09,0.2-0.50 \pm 0.22,0.3-0.49 \pm 0.18$, protein: $0.1-0.63 \pm 0.09$, $0.2-0.61 \pm 0.12,0.3-0.55 \pm 0.14$, respectively; $P<0.05$ ) (Fig. 6C,D). In addition, protein expression of keratin 1 and involucrin in HNKs $24 \mathrm{~h}$ and $72 \mathrm{~h}$ after all ESWT regimens significantly higher and lower than that of those in untreated control cells, respectively (keratin 1: $0.1-1.35 \pm 0.09,0.2-1.49 \pm 0.10,0.3-1.43 \pm 0.11$-fold increase at $24 \mathrm{~h}, 0.1-0.31 \pm 0.04,0.2-0.39 \pm 0.03,0.3-0.37 \pm 0.03$-fold decrease at $72 \mathrm{~h}$; keratin $17: 0.1-1.33$ $\pm 0.11,0.2-1.54 \pm 0.13,0.3-1.85 \pm 0.18$-fold increase at $24 \mathrm{~h}, 0.1-0.34 \pm 0.04,0.2-0.28 \pm 0.03,0.3-0.27 \pm$ 0.04 -fold decrease at $72 \mathrm{~h}$, respectively; $P<0.05$ ) (Figure S3 D and E).

Effect of ESWT on expression of apoptosis-related factors in HTSKs. The pro-apoptotic factor Bax expression at mRNA and protein levels in HTSKs $24 \mathrm{~h}$ and $72 \mathrm{~h}$ after ESWT significantly higher and lower than that of those in untreated control cells (mRNA: $0.1-2.06 \pm 0.23,0.2-2.08 \pm 0.20$, and $0.3-2.46 \pm 0.26$ fold increase at $24 \mathrm{~h}, 0.1-0.47 \pm 0.16,0.2-0.51 \pm 0.15$, and $0.3-0.50 \pm 0.13$-fold decrease at $72 \mathrm{~h}$, protein: $0.1-$ $1.40 \pm 0.09,0.2-1.43 \pm 0.12$, and $0.3-1.62 \pm 0.15$-fold increase at $24 \mathrm{~h}, 0.1-0.55 \pm 0.07,0.2-0.60 \pm 0.05$, and $0.3-0.61 \pm 0.07$-fold decrease at $72 \mathrm{~h}$, respectively; $P<0.05$ ) (Fig. 7A,B). Anti-apoptosis factor Bcl 2 expression was in accordance with Bax expression at mRNA and protein levels (mRNA: $0.1-1.87 \pm 0.20,0.2-1.94 \pm 0.17$, and $0.3-1.99 \pm 0.19$-fold increase at $24 \mathrm{~h}, 0.1-0.56 \pm 0.09,0.2-0.55 \pm 0.08$, and $0.3-0.52 \pm 0.10$-fold decrease at $72 \mathrm{~h}$, protein: $0.1-1.27 \pm 0.10,0.2-1.32 \pm 0.13$, and $0.3-1.35 \pm 0.12$-fold increase at $24 \mathrm{~h}, 0.1-0.67 \pm 0.08$, $0.2-0.69 \pm 0.07$, and $0.3-0.63 \pm 0.09$-fold decrease at $72 \mathrm{~h}$, respectively; $P<0.05$ ) (Fig. $7 \mathrm{C}, \mathrm{D})$. Apoptosis signalregulating kinase 1 (ASK1) expression at mRNA and protein levels in HTSKs $24 \mathrm{~h}$ and $72 \mathrm{~h}$ after ESWT significantly higher than that of those in untreated control cells (mRNA: $0.1-1.87 \pm 0.11,0.2-1.85 \pm 0.10$, and $0.3-1.91 \pm 0.10$-fold increase at $24 \mathrm{~h}, 0.1-1.77 \pm 0.14,0.2-1.92 \pm 0.19$, and $0.3-2.06 \pm 0.19$-fold increase at 


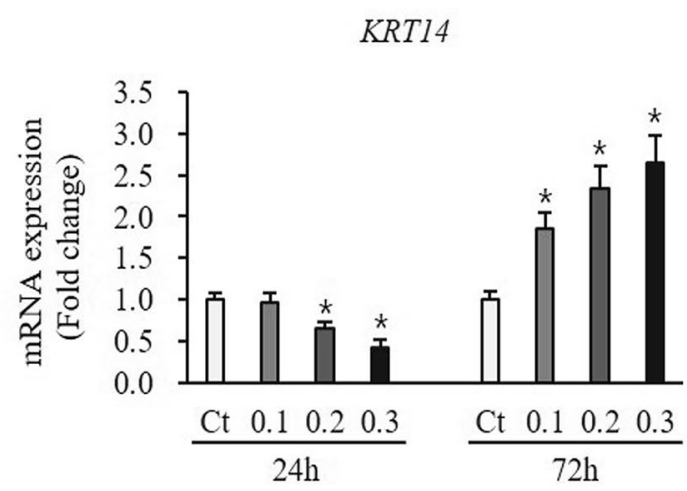

C

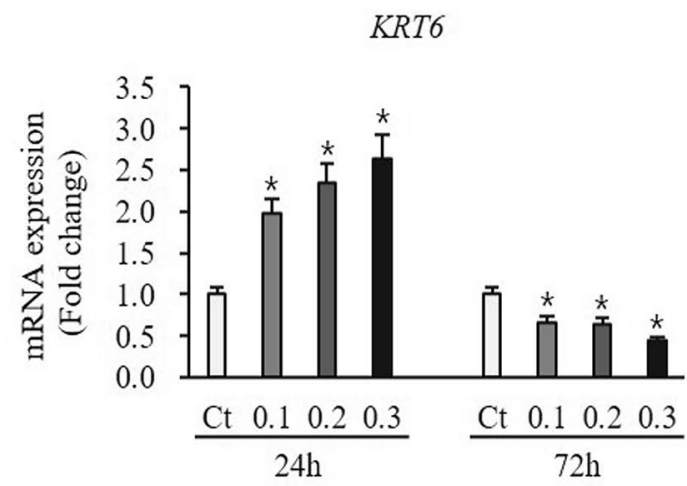

E

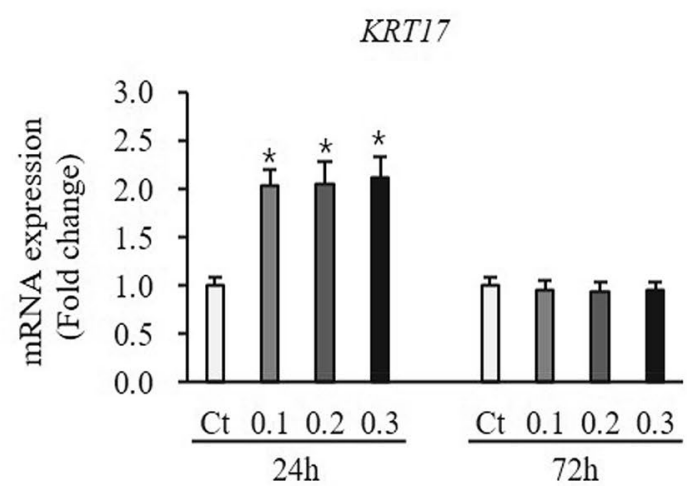

Keratin 14

$\beta$-actin

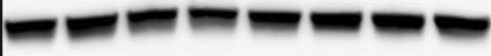

ßractin

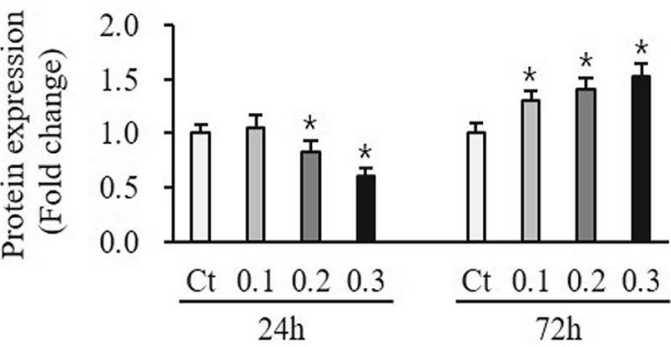

D

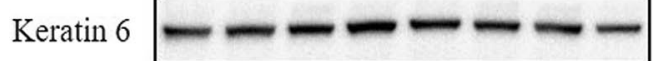

$\beta$-actin
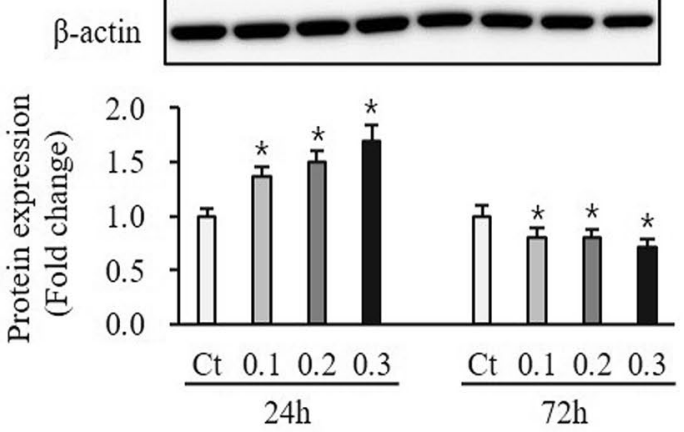

F

Keratin 17

$\beta$-actin
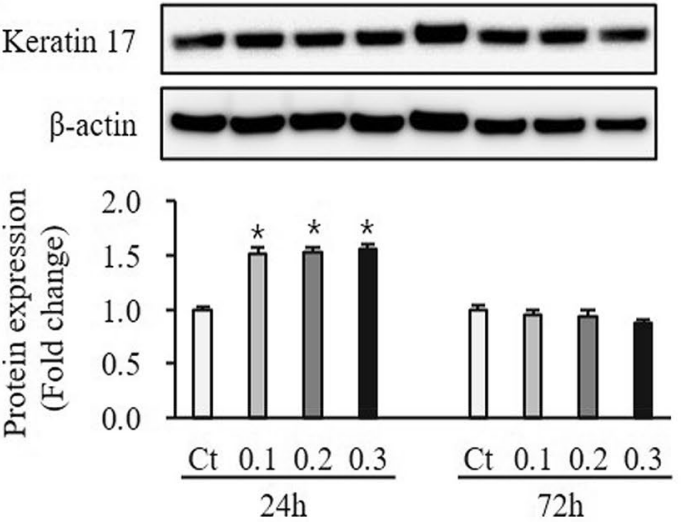

Figure 5. Expression of proliferation and activation marker in HTSKs after ESWT. Significantly decreased and increased mRNA (A) and protein levels (B) of keratin 14 (KRT14), a proliferation marker in HTSKs at $24 \mathrm{~h}$ or $72 \mathrm{~h}$ after ESWT under 0.2 , and $0.3 \mathrm{~mJ} / \mathrm{mm}^{2}$ of energy flux density, comparted with those in untreated control. Significantly increased and decreased mRNA (C) and protein levels (D) of keratin 6 (KRT6), an activation marker in HTSKs at $24 \mathrm{~h}$ or $72 \mathrm{~h}$ after ESWT under $0.1,0.2$, and $0.3 \mathrm{~mJ} / \mathrm{mm}^{2}$ of energy flux density, comparted with those in untreated control. Significantly increased and unchanged mRNA (E) and protein levels (F) of keratin 17 (KRT17), anther activation marker in HTSKs at $24 \mathrm{~h}$ or $72 \mathrm{~h}$ after ESWT, comparted with those in untreated control. In the fold change, untreated control cells marked as value 1; Ct, untreated control cells; HTSK, hypertrophic scar keratinocyte; ${ }^{*} P<0.05$ for ESWT-treated cells vs. the corresponding matched untreated control cells. Data represent means $\pm \mathrm{SD} ; \mathrm{n}=4$. 
A

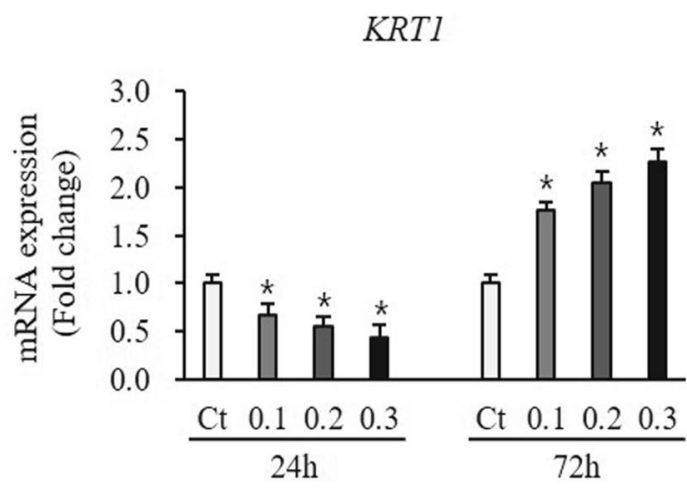

C

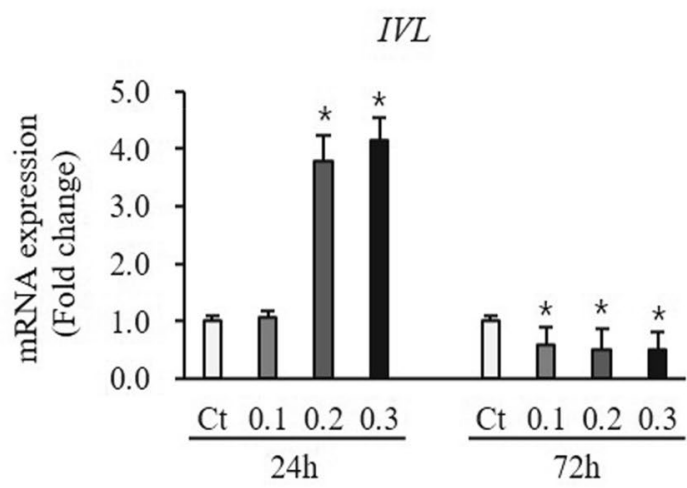

B

Keratin 1

$\beta$-actin

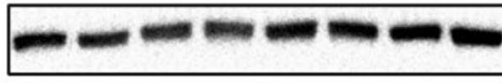

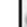

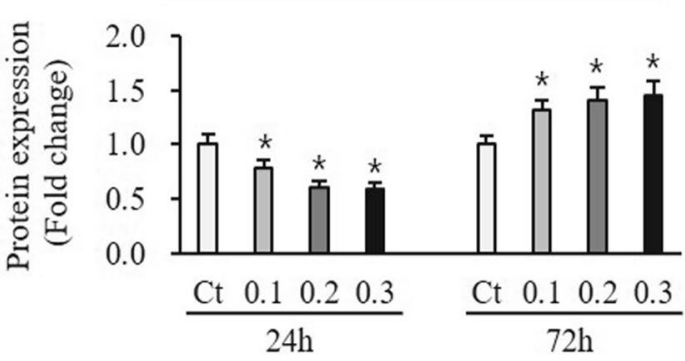

D

Involucrin

$\beta$-actin
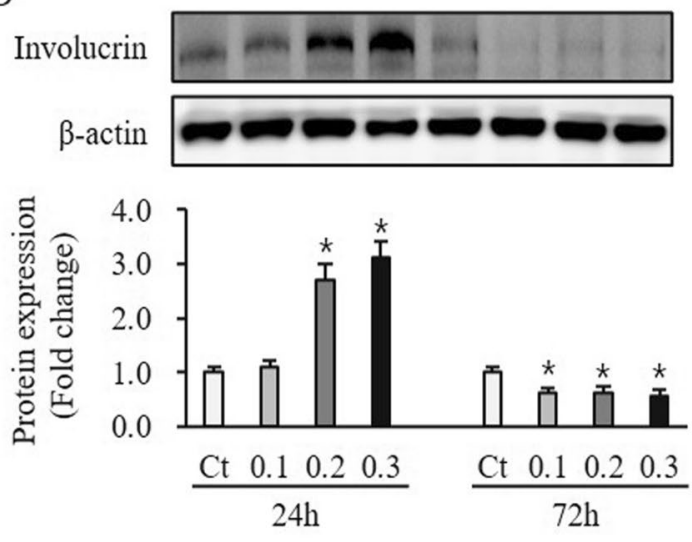

Figure 6. Expression of differentiation marker in HTSKs after ESWT. Significantly decreased and increased mRNA (A) and protein levels (B) of keratin 1 (KRT1) in HTSKs at $24 \mathrm{~h}$ or $72 \mathrm{~h}$ after ESWT under 0.1, 0.2, and $0.3 \mathrm{~mJ} / \mathrm{mm}^{2}$ of energy flux density, comparted with those in untreated control. Significantly increased and decreased mRNA (C) and protein levels (D) of involucrin (IVL) in HTSKs at $24 \mathrm{~h}$ or $72 \mathrm{~h}$ after ESWT, comparted with those in untreated control. In the fold change, untreated control cells marked as value 1 ; $\mathrm{Ct}$, untreated control cells; HTSK, hypertrophic scar keratinocyte; ${ }^{*} P<0.05$ for ESWT-treated cells vs. the corresponding matched untreated control cells. Data represent means $\pm S D ; n=4$.

control cells (mRNA: $0.1-1.15 \pm 0.11,0.2-1.17 \pm 0.13$, and $0.3-1.16 \pm 0.12$-fold, protein: $0.1-1.13 \pm 0.10$, $0.2-1.14 \pm 0.11$, and $0.3-1.21 \pm 0.15$-fold, respectively; $P>0.05$ ) (Fig. $7 \mathrm{G}, \mathrm{H}$ ). However, they were significantly increased $72 \mathrm{~h}$ after treatment compared with untreated control cells (mRNA: $0.1-2.26 \pm 0.19,0.2-2.35 \pm 0.18$, and $0.3-2.57 \pm 0.16$-fold increase, protein: $0.1-1.55 \pm 0.11,0.2-1.58 \pm 0.12$, and $0.3-1.67 \pm 0.13$-fold increase, respectively; $P<0.05$ ) (Fig. 7G,H). These results indicate ESWT may regulate HTSKs apoptosis.

Effect of ESWT on expression of proliferation and differentiation regulators in HTSKs. The p21, p27, and Notch1 expression at mRNA and protein levels in HTSKs $24 \mathrm{~h}$ after ESWT under $0.1 \mathrm{~mJ} / \mathrm{mm}^{2} \mathrm{was}$ not significantly changed, when compared with that of those in untreated cells $(\mathrm{p} 21-\mathrm{mRNA}: 0.1-0.87 \pm 0.12$, p27-mRNA: $0.1-1.10 \pm 0.11$, Notch $1-$ mRNA: $0.1-1.12 \pm 0.09$, p21-protein: $0.1-0.81 \pm 0.21$, p27-protein: $0.1-1.08 \pm 0.07$, Notch $1-$ protein: $0.1-1.06 \pm 0.16$, respectively; $P>0.05$ ) (Fig. 8). However, they at mRNA and protein levels in HTSKs $24 \mathrm{~h}$ after ESWT under 0.2 and $0.3 \mathrm{~mJ} / \mathrm{mm}^{2}$ were significantly higher than that of those in untreated cells (p21-mRNA: $0.2-1.86 \pm 0.13,0.3-2.34 \pm 0.20, \mathrm{p} 27-$ mRNA: $0.2-2.44 \pm 0.27,0.3-$ $3.18 \pm 0.39$; Notch $1-$ mRNA: $0.2-1.75 \pm 0.11,0.3-1.98 \pm 0.20$, p $21-$ protein: $0.2-1.35 \pm 0.11,0.3-1.67 \pm 0.08$, p27-protein: $0.2-1.64 \pm 0.14,0.3-1.91 \pm 0.16$; Notch 1-protein $0.2-1.31 \pm 0.08,0.3-1.54 \pm 0.09$, respectively; $P<0.05$ ) (Fig. 8). Moreover, they at mRNA and protein levels $72 \mathrm{~h}$ after ESWT under all regimens were significantly lower than that of those in untreated control cells (p21-mRNA: $0.1-0.57 \pm 0.09,0.2-0.46 \pm 0.12,0.3-$ $0.44 \pm 0.14$, p $27-$ mRNA: $0.1-0.29 \pm 0.10,0.2-0.43 \pm 0.16,0.3-0.40 \pm 0.11$; Notch $1-$ mRNA: $0.1-0.52 \pm 0.09$, $0.2-0.56 \pm 0.11,0.3-0.56 \pm 0.11, \mathrm{p} 21-$ protein: $0.1-0.44 \pm 0.25,0.2-0.56 \pm 0.12,0.3-0.55 \pm 0.10$, p27-protein: $0.1-0.32 \pm 0.07,0.2-0.49 \pm 0.06,0.3-0.48 \pm 0.05$; Notch 1 -protein: $0.1-0.51 \pm 0.09,0.2-0.66 \pm 0.10$, $0.3-0.65 \pm 0.08$, respectively; $P<0.05$ ) (Fig. 8). These results indicate ESWT may regulate $\mathrm{p} 21, \mathrm{p} 27$, and Notch1 expression in HTSKs. 


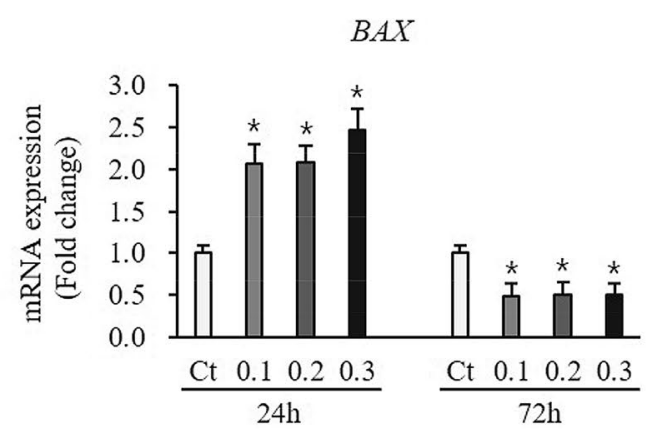

C

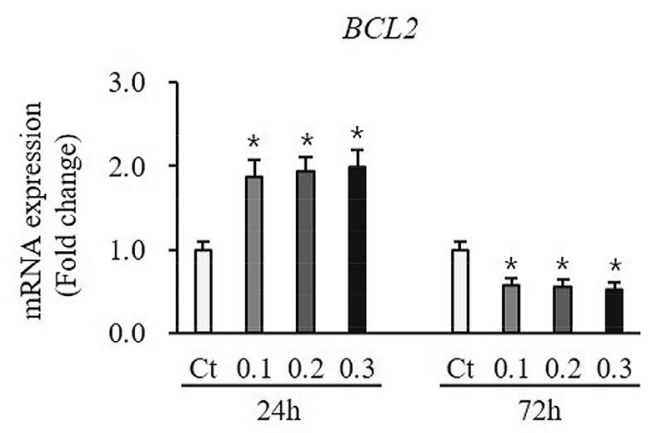

E

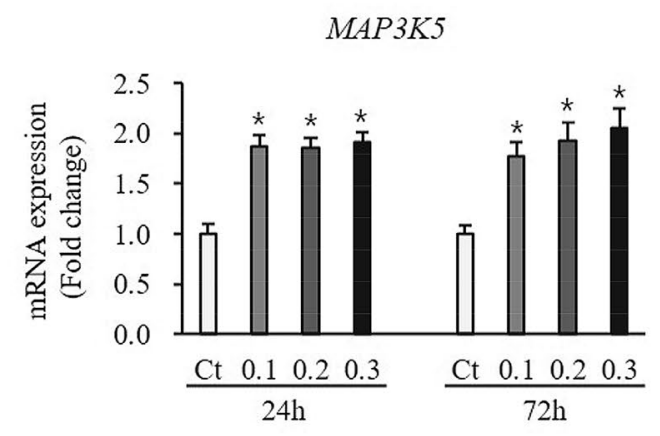

G

CASP14

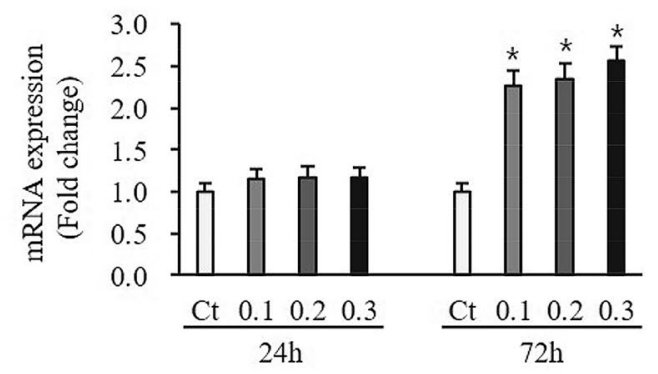

Bax

$\beta$-actin

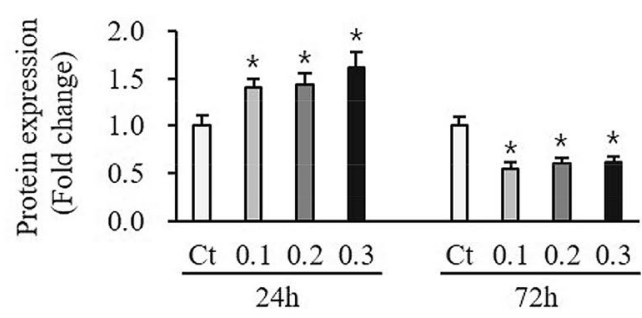

D

$\mathrm{Bcl} 2$

$\beta$-actin

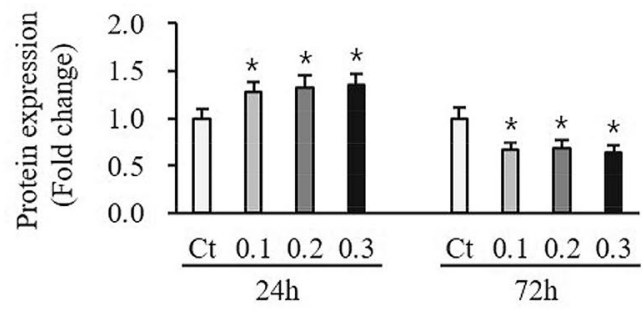

F

ASK1

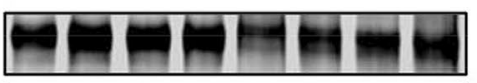

$\beta$-actin
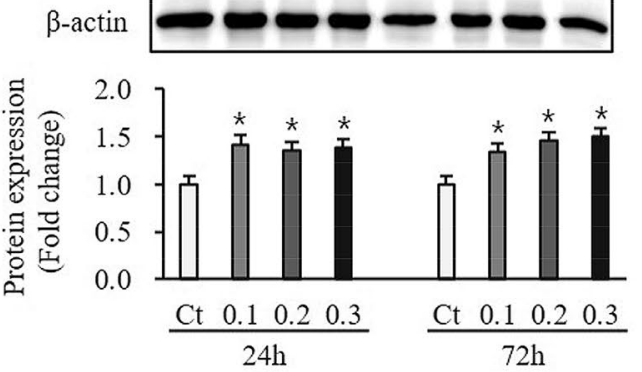

$\mathrm{H}$

Caspase 14

$\beta$-actin

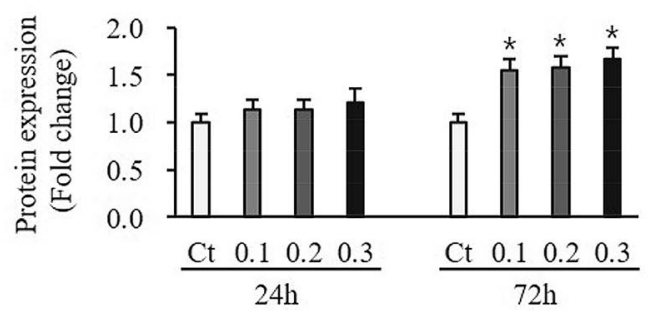

Figure 7. Expression of apoptosis-related factors in HTSKs. Significantly increased and decreased mRNA levels of bax $(B A X)(A)$ and bcl2 (BCL2) (C) in HTSKs at $24 \mathrm{~h}$ or $72 \mathrm{~h}$ after ESWT under $0.1,0.2$, and $0.3 \mathrm{~mJ} / \mathrm{mm}^{2}$ of energy flux density, comparted with those in untreated control. Significantly increased and decreased protein levels of bax (B) and bcl 2 (D) in HTSKs at $24 \mathrm{~h}$ or $72 \mathrm{~h}$ after ESWT, comparted with those in untreated control. Significantly increased mRNA (E) and protein levels (F) of ASK1 (MAP3K5) in HTSKs at $24 \mathrm{~h}$ or $72 \mathrm{~h}$ after ESWT, comparted with those in untreated control. Unchanged and significantly increased mRNA $(\mathbf{G})$ and protein levels $(\mathbf{H})$ of caspase 14 (CASP14) in HTSKs at $24 \mathrm{~h}$ or $72 \mathrm{~h}$ after ESWT, comparted with those in untreated control. In the fold change, untreated control cells marked as value 1; Ct, untreated control cells; HTSK, hypertrophic scar keratinocyte; ${ }^{\star} P<0.05$ for ESWT-treated cells vs. the corresponding matched untreated control cells. Data represent means $\pm S D ; n=4$. 
A

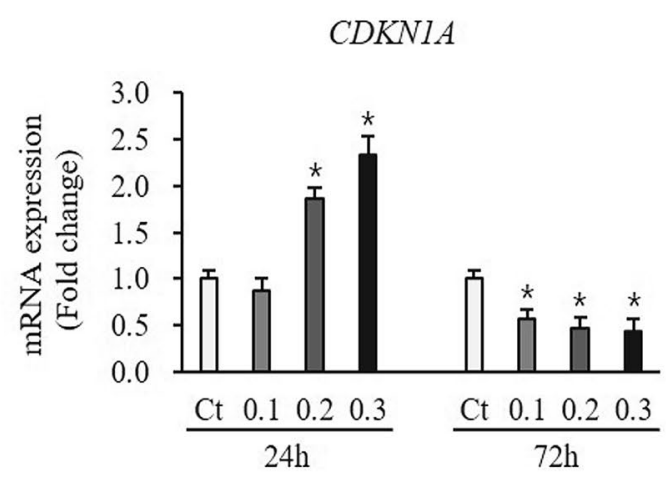

C

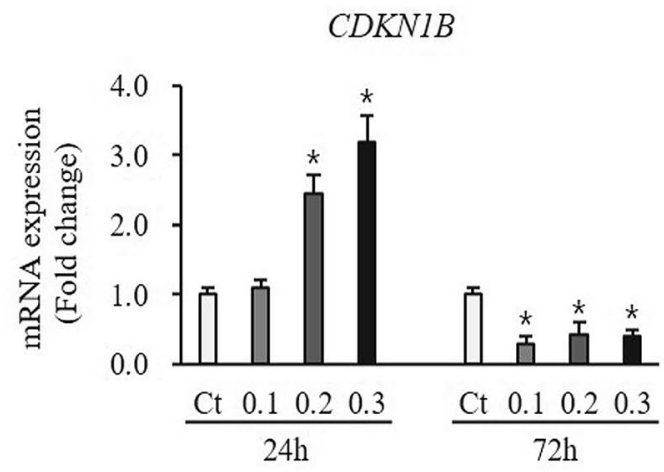

E

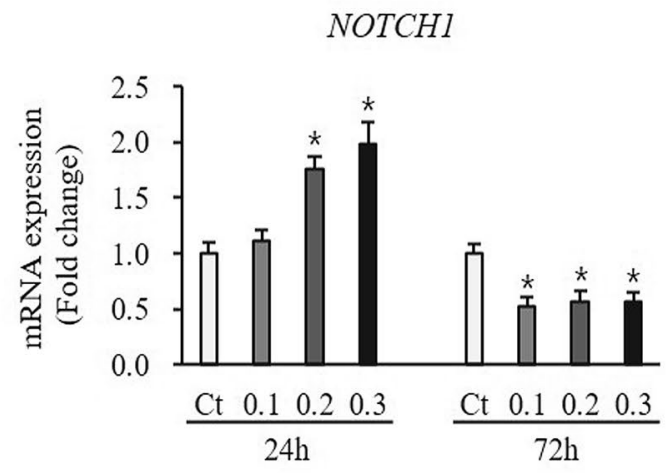

B

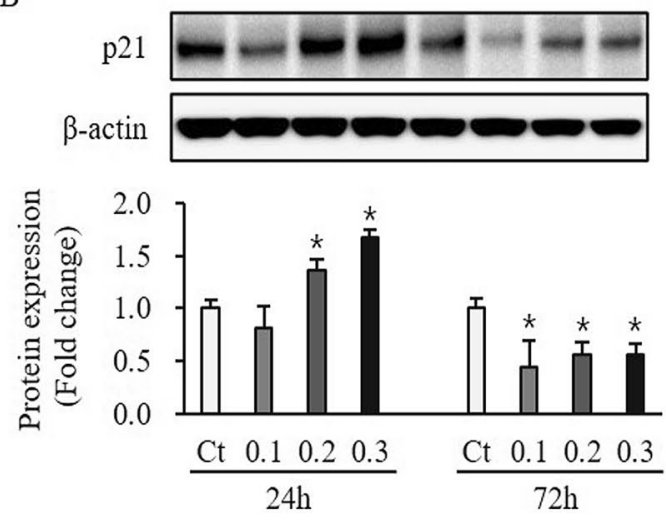

D

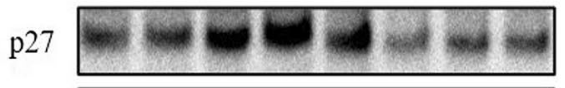

$\beta$-actin

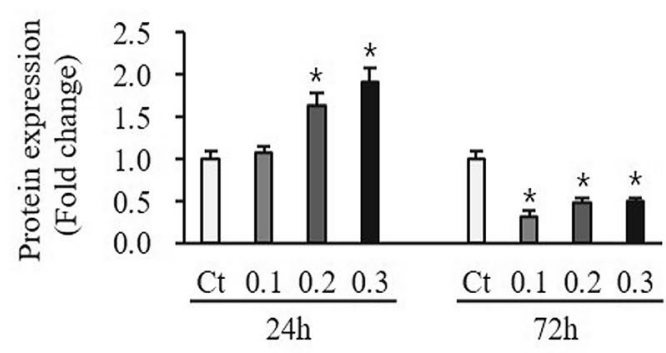

F
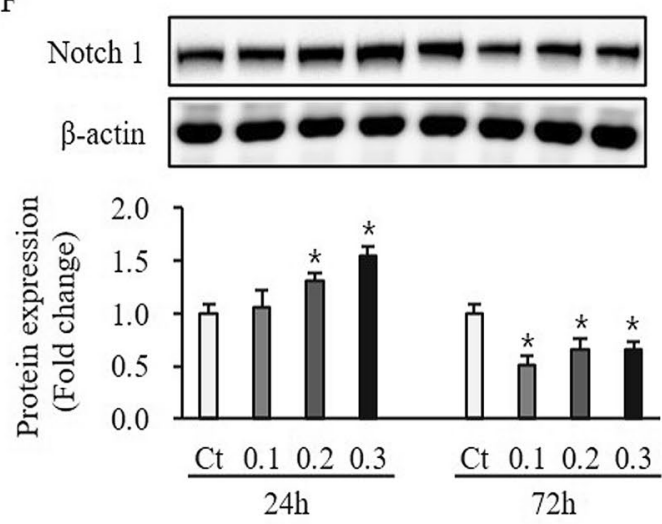

Figure 8. Expression of proliferation/differentiation regulators in HTSKs after ESWT. Significantly increased mRNA levels of genes encoding p21 (CDKN1A) (A), p27 (CDKN1B) (C), and Notch 1 (NOTCH1) (E) in HTSKs at $24 \mathrm{~h}$ after ESWT under 0.2 and $0.3 \mathrm{~mJ} / \mathrm{mm}^{2}$ of energy flux density, compared with those in untreated control. Significantly decreased mRNA levels of genes encoding p21 (CDKN1A) (A), p27 (CDKN1B) (C), and Notch 1 (NOTCH1) (E) in HTSKs at $72 \mathrm{~h}$ after ESWT under $0.1,0.2$, and $0.3 \mathrm{~mJ} / \mathrm{mm}^{2}$ of energy flux density, compared with those in untreated control. Significantly increased protein levels of p21 (B), p27 (D), and Notch 1 (F) in HTSKs at $24 \mathrm{~h}$ after ESWT under 0.2 and $0.3 \mathrm{~mJ} / \mathrm{mm}^{2}$ of energy flux density, compared with those in untreated control. Significantly decreased protein levels of p21 (B), p27 (D), and Notch 1 (F) in HTSKs at $72 \mathrm{~h}$ after ESWT, compared with those in untreated control. In the fold change, untreated control cells marked as value 1; Ct, untreated control cells; HTSK, hypertrophic scar keratinocyte; ${ }^{\star} P<0.05$ for ESWT-treated cells vs. the corresponding matched untreated control cells. Data represent means $\pm \mathrm{SD} ; \mathrm{n}=4$.

\section{Discussion}

Despite the clinical studies indicate that ESWT benefit to patients with post-burn hypertrophic scar (HTS) ${ }^{19,20,23,24}$, However, the molecular mechanisms underlying observed beneficial effects after ESWT have remained unclear. 


\begin{tabular}{|l|l|l|l|l|}
\hline Marker type & Protein and gene of interest & HTSKs compared to HNKs & After treatment $\mathbf{2 4} \mathbf{h}$ & After treatment 72 h \\
\hline Proliferation & Keratin 5 (KRT5) & n.c & n.c & n.c \\
\hline Proliferation & Keratin 14 (KRT14) & n.c & - & + \\
\hline Activation & Keratin 16 (KRT6) & + & + & - \\
\hline Activation & Keratin 17(KRT17) & + & + & n.c \\
\hline Differentiation & Keratin 1 (KRT1) & + & - & + \\
\hline Differentiation & Keratin 10 (KRT10) & - & n.c & n.c \\
\hline Differentiation & Involucrin $(I V L)$ & + & + & - \\
\hline Pro-apoptotic & Bax $(B A X)$ & -- & + & - \\
\hline Anti-apoptotic & Bcl2 (BCL2) & ++ & + & - \\
\hline Pro-apoptotic & Caspase 14 (CASP14) & -- & n.c & + \\
\hline Cell cycle regulator & p21 $(C D K N 1 A)$ & ++ & + & - \\
\hline Cell cycle regulator & p27 $(C D K N 1 B)$ & ++ & + & - \\
\hline
\end{tabular}

Table 3. Impact of the effect of ESWT on human hypertrophic scar keratinocytes. + indicates fold change from control $<2.0$. ++ indicates fold change from control $>2.0$. - indicates fold change from control 0.0 to -0.5 . - indicates fold change $>-0.5$. $n . c$ not changed.

In previous in vitro study in the fibroblasts derived from HTS, we demonstrated shock wave therapy had an antifibrotic effect ${ }^{12}$. Present study, we investigated the molecular changes of HTSKs after ESWT to provide an evidence for clinical application.

In the literature on the ESWT, no agreement on how to achieve maximum potential. There are several in vitro studies has been used with $100-300$ pulses at $0.03-0.13 \mathrm{~mJ} / \mathrm{mm}^{2}$ in mesenchymal cell line ${ }^{14}, 1000$ impulses at $0.14 \mathrm{~mJ} / \mathrm{mm}^{2}$ in human tenocytes ${ }^{25}$, and $0.06-0.50 \mathrm{~mJ} / \mathrm{mm}^{2}$ in human osteoblasts ${ }^{26}$. Recent we applied ESWT with $4 \mathrm{~Hz}$ frequency, $0.05-0.30 \mathrm{~mJ} / \mathrm{mm}^{2}$ energy flux density, and 1000 to $2000 \mathrm{impulses} / \mathrm{cm}^{2}$ per treatment according to patient's tolerance to pain. This treatment improved scar thickness, vascularity, and functionality, when treat to HTS of hand without obvious side effects ${ }^{24}$. Moreover, in our previous study, that ESWT with $1000 \mathrm{impulses} / \mathrm{cm}^{2}$ at $0.03,0.1$, and $0.3 \mathrm{~mJ} / \mathrm{mm}^{2}$ not only altered the expression of fibrosis-related molecules in fibroblast derived from HTS, but did not affected the cells viability. Therefore, in this study, we selected the parameter with $1000 \mathrm{impulses} / \mathrm{cm}^{2}$ at $0.1,0.2$, and $0.3 \mathrm{~mJ} / \mathrm{mm}^{2}$, applied to keratinocytes, and determined the molecular changes of cells.

At present, the fundamental epidermal pathology of HTS is still unclear. In previous studies, determined the expression of keratin 5 and 14, both are proliferation marker, and keratin 6, 16, and 17, they are activation marker by immunohistochemistry in HTS tissues that provided evidence that HTSKs were activated, but there was no difference in proliferation compared with site matched normal skin tissues ${ }^{27}$. Moreover, differentiation marker, filaggrin and involucrin were abnormally detected in $\mathrm{HTS}^{27,28}$. The increased expression of involucrin also found in other hyperproliferative disease, such as psoriasis ${ }^{29}$. The authors considered that abnormal expression of involucrin possibly affect stratum corneum formation ${ }^{28}$. In our results, the characteristic of HTSKs is similar to those of above previous study that is activated keratinocytes highly expressed keratin 6 and 17, and involucrin expression was also increased. Activated keratinocytes may play an important role in the development of HTS through the epidermal-mesenchymal interaction ${ }^{17}$. In HTSKs, the anti-apoptotic factor Bcl 2 expression at mRNA and protein levels increased, while pro-apoptotic factor Bax expression was unchanged, compared to HNKs that suggest up-regulated anti-apoptosis in HTSKs. This results also reflect the low level of apoptosis is a cause of HTS formation $^{30}$. The differentiation marker, keratin 1 and involucrin expression were increased in HTSKs, suggest differentiation of HTSKs was increased than HNKs. Moreover, the cell cycle regulator, p21 and p27 expression were also up-regulated in HTSKs. Study revelated the keratinocyte proliferation and differentiation were tightly regulated by the p21 and p27 expression. Moreover, over-expression of p21 and p27 induced keratinocyte differentiation and inhibited proliferation ${ }^{31}$. On the contrary, down-regulation of p21 and p27 expression resulted inhibition of differentiation with decrease of keratin-1 expression ${ }^{32}$. Therefore, increased expression of keratin 1 and involucrin may be related to up-regulated p21 and p27 expression in HTSKs.

We found the proliferation marker, keratin 14 expression was decreased at $24 \mathrm{~h}$ and increased at $72 \mathrm{~h}$, while activation marker keratin 6 expression was increased at $24 \mathrm{~h}$ and decreased at $72 \mathrm{~h}$. Moreover, early time differentiation marker keratin 1 expression was decreased at $24 \mathrm{~h}$ and increased at $72 \mathrm{~h}$, and later differentiation marker, involucrin was increased at $24 \mathrm{~h}$ and decreased at $72 \mathrm{~h}$. These results indicate that ESWT coordinately regulate HTSKs proliferation, activation, and differentiation, rather than blindly increase or decrease. Whereas, expression of keratin 6, and keratin 1 and involucrin in HNKs at $24 \mathrm{~h}$ after ESWT was increased and decreased at $72 \mathrm{~h}$. These results suggest that ESWT exhibit different effects depending on physiological phenotypes. To maintain normal epidermal integrity, the proliferation-differentiation-death cycle must operate seamlessly. The several apoptosis-related factors physiologically involved in keratinocyte proliferation and differentiation ${ }^{33}$, including Bax, Bcl2, ASK1, and Caspase 14 etc. In normal epidermal development, Bcl-2 is highly expressed in basal proliferating keratinocytes and absent from suprabasal keratinocytes ${ }^{34}$. Bax expression has been reported to be stronger in suprabasal than in basal keratinocytes ${ }^{35}$. Over-expression of ASK1 in keratinocytes doses not induce apoptosis, but induce cell differentiation along with increasing the expression of involucrin ${ }^{36}$. Caspase-14 is uniquely expressed in skin tissues unlike other caspases type expressed ubiquitously ${ }^{37}$ and its accumulation is 
associated with keratinocyte differentiation and stratum corneum formation ${ }^{38}$. In our results, Bcl2 expression was correlated with Bax expression increased at $24 \mathrm{~h}$ decreased at $72 \mathrm{~h}$ after ESWT. Moreover, ASK1 expression was increased at $24 \mathrm{~h}$ and $72 \mathrm{~h}$ after ESWT. Caspase 14 expression was increased just at $72 \mathrm{~h}$ after treatment. These results are further supported the effect of shock wave therapy regulate HTSKs proliferation and differentiation. To sum up the above, that over- or down-expression of apoptosis-related factors reflects ESWT treatment induces the proliferation or differentiation phenotype keratinocyte.

Overall, the shock wave therapy altered the expression of proliferation and differentiation-related molecular in HTSKs. The increased or decreased expression of molecular in HTSKs $24 \mathrm{~h}$ or $72 \mathrm{~h}$ after treatment was close to that of those in the normal cell; for instance, keratin 1 expression at $24 \mathrm{~h}$, involucrin, bcl2, p21, and p27 expression at $72 \mathrm{~h}$ vs. that of those in HNKs. The consequence its dynamic regulation may be partially involved in pathological phenotype restore to normal cell physiological state contribute to maintain normal epidermal homeostasis.

Notch1, p21, and p27 are also involved in regulating the proliferation and differentiation of keratinocytes ${ }^{39-42}$. Specifically, activation of Notch 1 upregulation of p21 to induce differentiation associated cell arrest, whereas p27 activation promotes the differentiation of keratinocytes ${ }^{40-42}$. In our results, expression of Notch1, p21, and p27 was increased at $24 \mathrm{~h}$ and decreased at $72 \mathrm{~h}$ after ESWT. Their expression pattern was consistent with that expression of keratin 14 and involucrin. Therefore, the effect of ESWT on the proliferation and differentiation of HTSKs possibly through regulate expression of Notch1, p21, and p27.

In summary, present study demonstrated that extracorporeal shock wave dynamically regulates proliferation, activation, and differentiation of keratinocytes originated from hypertrophic scar tissue (Table 3). This evidence partially supports observed in clinical beneficial effects of shock wave therapy for post-burn hypertrophic scar. Future study will be carried out in a three-dimensional culture model to fully explore the mechanism of action and to provide more physiologically relevant information.

Received: 19 December 2020; Accepted: 11 August 2021

Published online: 27 August 2021

\section{References}

1. Aarabi, S., Longaker, M. T. \& Gurtner, G. C. Hypertrophic scar formation following burns and trauma: New approaches to treatment. PLoS Med. 4, e234. https://doi.org/10.1371/journal.pmed.0040234 (2007).

2. Choi, Y. H., Kim, K. M., Kim, H. O., Jang, Y. C. \& Kwak, I. S. Clinical and histological correlation in post-burn hypertrophic scar for pain and itching sensation. Ann. Dermatol. 25, 428-433. https://doi.org/10.5021/ad.2013.25.4.428 (2013).

3. Gauglitz, G. G., Korting, H. C., Pavicic, T., Ruzicka, T. \& Jeschke, M. G. Hypertrophic scarring and keloids: Pathomechanisms and current and emerging treatment strategies. Mol. Med. 17, 113-125. https://doi.org/10.2119/molmed.2009.00153 (2011).

4. Wang, C. J. Extracorporeal shockwave therapy in musculoskeletal disorders. J. Orthop. Surg. Res. 7, 11. https://doi.org/10.1186/ 1749-799x-7-11 (2012).

5. Mittermayr, R. et al. Extracorporeal shock wave therapy (ESWT) for wound healing: Technology, mechanisms, and clinical efficacy. Wound Repair Regen. 20, 456-465. https://doi.org/10.1111/j.1524-475X.2012.00796.x (2012).

6. Wang, C. J. et al. Shock wave therapy induces neovascularization at the tendon-bone junction. A study in rabbits. J. Orthop. Res. 21, 984-989. https://doi.org/10.1016/s0736-0266(03)00104-9 (2003).

7. Yu, T. et al. Shockwaves increase T-cell proliferation and IL-2 expression through ATP release, P2X7 receptors, and FAK activation. Am. J. Physiol. Cell Physiol. 298, C457-464. https://doi.org/10.1152/ajpcell.00342.2009 (2010).

8. Hatton, J. P., Pooran, M., Li, C. F., Luzzio, C. \& Hughes-Fulford, M. A short pulse of mechanical force induces gene expression and growth in MC3T3-E1 osteoblasts via an ERK 1/2 pathway. J. Bone Miner. Res. 18, 58-66. https://doi.org/10.1359/jbmr.2003.18.1. 58 (2003).

9. Mariotto, S. et al. Extracorporeal shock waves: From lithotripsy to anti-inflammatory action by NO production. Nitric Oxide 12, 89-96. https://doi.org/10.1016/j.niox.2004.12.005 (2005).

10. Kuo, Y. R. et al. Extracorporeal shock wave treatment modulates skin fibroblast recruitment and leukocyte infiltration for enhancing extended skin-flap survival. Wound Repair Regen. 17, 80-87. https://doi.org/10.1111/j.1524-475X.2008.00444.x (2009).

11. Davis, T. A. et al. Extracorporeal shock wave therapy suppresses the early proinflammatory immune response to a severe cutaneous burn injury. Int. Wound J. 6, 11-21. https://doi.org/10.1111/j.1742-481X.2008.00540.x (2009).

12. Cui, H. S. et al. Extracorporeal shock wave therapy alters the expression of fibrosis-related molecules in fibroblast derived from human hypertrophic scar. Int. J. Mol. Sci. https://doi.org/10.3390/ijms19010124 (2018).

13. Wang, F. S. et al. Ras induction of superoxide activates ERK-dependent angiogenic transcription factor HIF-1alpha and VEGF-A expression in shock wave-stimulated osteoblasts. J. Biol. Chem. 279, 10331-10337. https://doi.org/10.1074/jbc.M308013200 (2004).

14. Weihs, A. M. et al. Shock wave treatment enhances cell proliferation and improves wound healing by ATP release-coupled extracellular signal-regulated kinase (ERK) activation. J. Biol. Chem. 289, 27090-27104. https://doi.org/10.1074/jbc.M114.580936 (2014).

15. Lee, K. W., Kim, S. B., Lee, J. H. \& Kim, Y. S. Effects of extracorporeal shockwave therapy on improvements in lymphedema, quality of life, and fibrous tissue in breast cancer-related lymphedema. Ann. Rehabil. Med. 44, 386-392. https://doi.org/10.5535/arm. $19213(2020)$.

16. Djedovic, G., Kamelger, F. S., Jeschke, J. \& Piza-Katzer, H. Effect of extracorporeal shock wave treatment on deep partial-thickness burn injury in rats: A pilot study. Plast. Surg. Int. 2014, 495967. https://doi.org/10.1155/2014/495967 (2014).

17. Werner, S., Krieg, T. \& Smola, H. Keratinocyte-fibroblast interactions in wound healing. J. Invest. Dermatol. 127, 998-1008. https:// doi.org/10.1038/sj.jid.5700786 (2007).

18. Bellemare, J. et al. Epidermis promotes dermal fibrosis: Role in the pathogenesis of hypertrophic scars. J. Pathol. 206, 1-8. https:// doi.org/10.1002/path.1737 (2005).

19. Cho, Y. S. et al. Effect of extracorporeal shock wave therapy on scar pain in burn patients: A prospective, randomized, single-blind, placebo-controlled study. Medicine (Baltimore) 95, e4575. https://doi.org/10.1097/md.0000000000004575 (2016).

20. Joo, S. Y., Cho, Y. S. \& Seo, C. H. The clinical utility of extracorporeal shock wave therapy for burn pruritus: A prospective, randomized, single-blind study. Burns 44, 612-619. https://doi.org/10.1016/j.burns.2017.09.014 (2018).

21. Cui, H. S. et al. Wound healing potential of low temperature plasma in human primary epidermal keratinocytes. Tissue Eng. Regen. Med. 16, 585-593. https://doi.org/10.1007/s13770-019-00215-w (2019).

22. Freedberg, I. M., Tomic-Canic, M., Komine, M. \& Blumenberg, M. Keratins and the keratinocyte activation cycle. J. Invest. Dermatol. 116, 633-640. https://doi.org/10.1046/j.1523-1747.2001.01327.x (2001). 
23. Fioramonti, P. et al. Extracorporeal shock wave therapy for the management of burn scars. Dermatol. Surg. 38, 778-782. https:// doi.org/10.1111/j.1524-4725.2012.02355.x (2012).

24. Joo, S. Y., Lee, S. Y., Cho, Y. S. \& Seo, C. H. Clinical utility of extracorporeal shock wave therapy on hypertrophic scars of the hand caused by burn injury: A prospective, randomized, double-blinded study. J. Clin. Med. https://doi.org/10.3390/jcm9051376 (2020).

25. Vetrano, M. et al. Extracorporeal shock wave therapy promotes cell proliferation and collagen synthesis of primary cultured human tenocytes. Knee Surg. Sports Traumatol. Arthrosc. 19, 2159-2168. https://doi.org/10.1007/s00167-011-1534-9 (2011).

26. Hofmann, A. et al. Extracorporeal shock wave-mediated changes in proliferation, differentiation, and gene expression of human osteoblasts. J. Trauma 65, 1402-1410. https://doi.org/10.1097/TA.0b013e318173e7c2 (2008).

27. Machesney, M., Tidman, N., Waseem, A., Kirby, L. \& Leigh, I. Activated keratinocytes in the epidermis of hypertrophic scars. Am. J. Pathol. 152, 1133-1141 (1998).

28. Limandjaja, G. C. et al. Increased epidermal thickness and abnormal epidermal differentiation in keloid scars. Br. J. Dermatol. 176, 116-126. https://doi.org/10.1111/bjd.14844 (2017).

29. Gnanaraj, P. et al. Downregulation of involucrin in psoriatic lesions following therapy with propylthiouracil, an anti-thyroid thioureylene: Immunohistochemistry and gene expression analysis. Int. J. Dermatol. 54, 302-306. https://doi.org/10.1111/ijd.12565 (2015).

30. Armour, A., Scott, P. G. \& Tredget, E. E. Cellular and molecular pathology of HTS: Basis for treatment. Wound Repair. Regen. 15(Suppl 1), S6-17. https://doi.org/10.1111/j.1524-475X.2007.00219.x (2007).

31. Cabodi, S. et al. A PKC-eta/Fyn-dependent pathway leading to keratinocyte growth arrest and differentiation. Mol. Cell 6, 11211129. https://doi.org/10.1016/s1097-2765(00)00110-6 (2000).

32. Missero, C., Di Cunto, F., Kiyokawa, H., Koff, A. \& Dotto, G. P. The absence of p21Cip1/WAF1 alters keratinocyte growth and differentiation and promotes ras-tumor progression. Genes Dev. 10, 3065-3075. https://doi.org/10.1101/gad.10.23.3065 (1996).

33. Raj, D., Brash, D. E. \& Grossman, D. Keratinocyte apoptosis in epidermal development and disease. J. Invest. Dermatol. 126, 243-257. https://doi.org/10.1038/sj.jid.5700008 (2006).

34. Hockenbery, D. M., Zutter, M., Hickey, W., Nahm, M. \& Korsmeyer, S. J. BCL2 protein is topographically restricted in tissues characterized by apoptotic cell death. Proc. Natl. Acad. Sci. U S A 88, 6961-6965. https://doi.org/10.1073/pnas.88.16.6961 (1991).

35. Tomková, H., Fujimoto, W. \& Arata, J. Expression of the bcl-2 homologue bax in normal human skin, psoriasis vulgaris and nonmelanoma skin cancers. Eur. J. Dermatol. 8, 256-260 (1998).

36. Sayama, K. et al. Apoptosis signal-regulating kinase 1 (ASK1) is an intracellular inducer of keratinocyte differentiation. J. Biol. Chem. 276, 999-1004. https://doi.org/10.1074/jbc.M003425200 (2001).

37. Van de Craen, M. et al. Identification of a new caspase homologue: Caspase-14. Cell Death Differ. 5, 838-846. https://doi.org/10. 1038/sj.cdd.4400444 (1998).

38. Eckhart, L. et al. Terminal differentiation of human keratinocytes and stratum corneum formation is associated with caspase-14 activation. J. Invest. Dermatol. 115, 1148-1151. https://doi.org/10.1046/j.1523-1747.2000.00205.x (2000).

39. Rangarajan, A. et al. Notch signaling is a direct determinant of keratinocyte growth arrest and entry into differentiation. Embo J. 20, 3427-3436. https://doi.org/10.1093/emboj/20.13.3427 (2001).

40. Okuyama, R., LeFort, K. \& Dotto, G. P. A dynamic model of keratinocyte stem cell renewal and differentiation: Role of the p21WAF1/Cip1 and Notch1 signaling pathways. J. Investig. Dermatol. Symp. Proc. 9, 248-252. https://doi.org/10.1111/j.1087-0024. 2004.09308.x (2004).

41. Kashiwagi, M. et al. PKCeta associates with cyclin E/cdk2/p21 complex, phosphorylates p21 and inhibits cdk2 kinase in keratinocytes. Oncogene 19, 6334-6341. https://doi.org/10.1038/sj.onc.1204028 (2000).

42. Hara, T., Miyazaki, M., Hakuno, F., Takahashi, S. \& Chida, K. PKC $\eta$ promotes a proliferation to differentiation switch in keratinocytes via upregulation of p27Kip1 mRNA through suppression of JNK/c-Jun signaling under stress conditions. Cell Death Dis. 2, e157. https://doi.org/10.1038/cddis.2011.40 (2011).

\section{Acknowledgements}

This research was supported by the Hallym University Research Fund HURF-2018-55.

\section{Author contributions}

H.S.C.: Conceptualization, Methodology, Writing - original draft. S.Y.J.: Supervision, Validation. Y.S.C.: Data curation, Visualization, Investigation. J.H.P. and Y.M.R.: Data collection. J.-B.K.: Supervision, Writing - review \& editing. C.H.S.: Conceptualization, Writing - review \& editing.

\section{Competing interests}

The authors declare no competing interests.

\section{Additional information}

Supplementary Information The online version contains supplementary material available at https://doi.org/ 10.1038/s41598-021-96537-8.

Correspondence and requests for materials should be addressed to J.-B.K. or C.H.S.

Reprints and permissions information is available at www.nature.com/reprints.

Publisher's note Springer Nature remains neutral with regard to jurisdictional claims in published maps and institutional affiliations.

Open Access This article is licensed under a Creative Commons Attribution 4.0 International License, which permits use, sharing, adaptation, distribution and reproduction in any medium or format, as long as you give appropriate credit to the original author(s) and the source, provide a link to the Creative Commons licence, and indicate if changes were made. The images or other third party material in this article are included in the article's Creative Commons licence, unless indicated otherwise in a credit line to the material. If material is not included in the article's Creative Commons licence and your intended use is not permitted by statutory regulation or exceeds the permitted use, you will need to obtain permission directly from the copyright holder. To view a copy of this licence, visit http://creativecommons.org/licenses/by/4.0/.

(C) The Author(s) 2021 